Check for updates

Cite this: RSC Adv., 2019, 9, 26252

Received 9th July 2019

Accepted 24th July 2019

DOI: $10.1039 / c 9 r a 05214 c$

rsc.li/rsc-advances

\section{Biomaterials for bone tissue engineering scaffolds: a review}

\author{
Huawei Qu, (D) ${ }^{a}$ Hongya Fu, ${ }^{\star a}$ Zhenyu Han ${ }^{a}$ and Yang Sun ${ }^{\star b}$
}

Bone tissue engineering has been continuously developing since the concept of "tissue engineering" has been proposed. Biomaterials that are used as the basic material for the fabrication of scaffolds play a vital role in bone tissue engineering. This paper first introduces a strategy for literature search. Then, it describes the structure, mechanical properties and materials of natural bone and the strategies of bone tissue engineering. Particularly, it focuses on the current knowledge about biomaterials used in the fabrication of bone tissue engineering scaffolds, which includes the history, types, properties and applications of biomaterials. The effects of additives such as signaling molecules, stem cells, and functional materials on the performance of the scaffolds are also discussed.

\section{Introduction}

Bone and its associated diseases, accounting for half of chronic diseases in people over 50 years old, still remain an important clinical challenge. ${ }^{1,2}$ Although bones have a certain healing and/or regeneration capacity, it cannot be accomplished by itself for large segmental bone defects. Large bone defects or injuries, caused by old age, traffic accident, fracture nonunion, bone tumor resection, etc., are serious problems in orthopaedics, and they bring great harms to health and the quality of life. ${ }^{3,4}$ Autologous bone grafting is still regarded as the "gold standard" for repairing bone defects. However, the drawbacks of autologous bone grafting include secondary damages, high donor site morbidity, limitation of special shape, insufficiency of autogenous bone and so on. These weaknesses limit its widespread use in clinical settings.

The term "tissue engineering" was first used in $1987 . .^{5}$ It is the utilization of a combination of multidisciplinary approaches to improve or replace biological tissues. In recent years, with the rapid development of tissue engineering technology, bone tissue engineering has become a hopeful approach for repairing bone defects. Scaffolds play a crucial role in bone tissue engineering. Their purpose is to mimic the structure and function of the natural bone extracellular matrix (ECM), which can provide a three-dimensional (3D) environment to promote the adhesion, proliferation, and differentiation and to have adequate physical properties for bone repair. An ideal scaffold should be biodegradable, biocompatible, bioactive, osteoconductive and

${ }^{a}$ School of Mechatronics Engineering, Harbin Institute of Technology, Harbin 150001, China.E-mail: hongyafu@hit.edu.cn

${ }^{b}$ School of Basic Medicine, Heilongjiang University of Chinese Medicine, Harbin 150030, China. E-mail: sunyang@hljucm.net osteoinductive. Artificial bone scaffolds with biomaterials and additives, such as drugs, growth factors (GFs) and stem cells, have been useful for bone repair.

The biomaterials (biomedical materials), which are basic components of scaffolds, play an important role in bone tissue engineering. Archaeological findings showed that materials such as human or animal bones and teeth, corals, shells, wood, and several metals (gold, silver and amalgam) were used for the replacement of missing human bones and teeth. ${ }^{6}$ For example, in the ancient times, the Etruscans learnt to replace damaged teeth with artificial graft obtained from the bones of oxen. In the early 1960s, the limitations of biological bone substitute materials resulted in the emergence of a multidisciplinary field called "Biomaterials". ${ }^{7}$ Biomaterials are used for the evaluation, treatment, augmentation, repair or replacement of tissues or organs of the body. Ancient alternative materials are mostly bioinert (biologically inert), and these materials interact less with the surrounding tissues and are even toxic to humans. An ideal biomaterial should be non-cytotoxic, printable, biodegradable, bioactive, and osteoconductive in vivo. Due to the various needs of scaffolds, composite materials composed of two or more materials with excellent properties are widely used in bone tissue engineering.

Numerous natural and synthetic polymers such as calcium phosphates, calcium carbonate, and bioactive glasses have been used to fabricate scaffolds. Recent outstanding approaches include the addition of conductive polymers (CPs), inducerons (signaling molecules, unlike bone morphogenetic protein 2 (BMP-2)) and mechanical signals (elastic polymer networks such as hydrogels) to bone tissue engineering scaffolds. With the integration, intercrossing and development of the fields of medicine, biology, materials and other disciplines, biomaterials have been extensively used in the fabrication of bone tissue engineering scaffolds. ${ }^{8}$ 
This article gives a brief introduction to the descriptions of the hierarchical structure, chemical composition of natural bone and strategies for bone tissue engineering. It aims to outline the history, types, properties and development methods of common biomaterials used to fabricate scaffolds. Further, the review also highlights the biomaterial scaffolds with additives. Finally, it examines the combination of advanced technology and biomaterials, and emphasizes the challenges and opportunities of biomaterials in bone tissue engineering scaffolds.

\section{Materials and methods}

All studies (in vitro and in vivo) concerning the application of biomaterials to manufacture scaffolds for bone tissue engineering were researched in duplicate in the Medline (PubMed) online database. The PubMed search was performed to look for articles published in English between January 1, 2010 and January 1, 2019. The Medical Subject Heading (abbreviated as $\mathrm{MeSH}$ ) terms "bone and bones", "biocompatible materials" and "tissue scaffolds" were used together with the keywords "bone tissue engineering", "biomaterials" and "scaffolds" to apply the following search strategy:

((("Bone and Bones[Mesh] OR (bone[All Fields]) OR (bones [All Fields]) OR ("bones and bone"[All Fields]) OR ("bones and bone tissues"[All Fields]) OR (bone[All Fields] AND (tissue[All Fields] OR tissues[All Fields])) OR ("bone tissue"[All Fields]) OR ("bone tissues"[All Fields])) AND ("biocompatible materials"[Mesh] OR ("biocompatible materials"[All Fields]) OR ((material[All Fields]) AND (biocompatible[All Fields])) OR (biomaterials[All Fields]) OR (biomaterial[All Fields]) OR ("bioartificial materials"[All Fields]) OR ("bioartificial material"[All Fields]) OR ((material[All Fields]) AND (bioartificial[All Fields]))) AND ("tissue scaffolds"[Mesh] OR ((scaffold[All Fields] OR scaffolds[All Fields] OR scaffolding[All Fields] OR scaffoldings [All Fields]) AND tissue[All Fields]) OR ("tissue scaffold"[All Fields]) OR ("tissue scaffolding"[All Fields]) OR ("tissue scaffoldings"[All Fields]))) OR ((bone tissue engineering) AND (biomaterials) AND (scaffolds))) AND ("2010/01/01"[DatePublication]: “2019/01/01"[Date-Publication]). ${ }^{\mathbf{9}, 10}$

The follow-up period or sample size is not limited. Meta analyses and systematic reviews were not included. Scientific research regarding the following topics was not considered: scaffolds for assisted positioning of transplants and help with surgical planning before the surgery.

\subsection{Study selection}

Two of the authors individually selected the titles and abstracts of the articles obtained by the above-mentioned search. Then, the selected studies were independently carefully sifted by both of the reviewers. Any disagreement was determined through discussions between them.

\subsection{Data extraction}

Two of the authors separately summarized the search and sought consensus among other authors in the process. The undermentioned information was recorded: the publication information including the author's name and publication data, the biomaterials applied to manufacture scaffolds and their important characteristics.

\section{Structure, mechanical properties and materials of natural bone}

\subsection{Hierarchical structure of bone}

As the main part of the human skeletal system, bone plays a crucial role in providing structure, supporting mechanical movement, protecting organs, and producing and hosting blood cells. It has a complex hierarchical structure based on the length and width scale, which consists of the macro scale (trabecular bone, also known as cancellous or spongy bone, and compact bone, also named cortical bone), microscale and submicroscale (haversian canals, osteons and lamellae), nanoscale (fibrillar collagen) and sub-nanoscale (such as minerals, collagen and so on), as shown in Fig. $1 .^{11}$ The structure of natural bone has been presented in various articles. ${ }^{11-21}$ Compact bone is nearly solid, except for $\sim 3-5 \%$ of rooms for canaliculi, osteocytes and so on. ${ }^{18}$ However, trabecular bone is an interconnected porous network and has a higher bone surface-to-bone volume (BS/BV) ratio than compact bone.

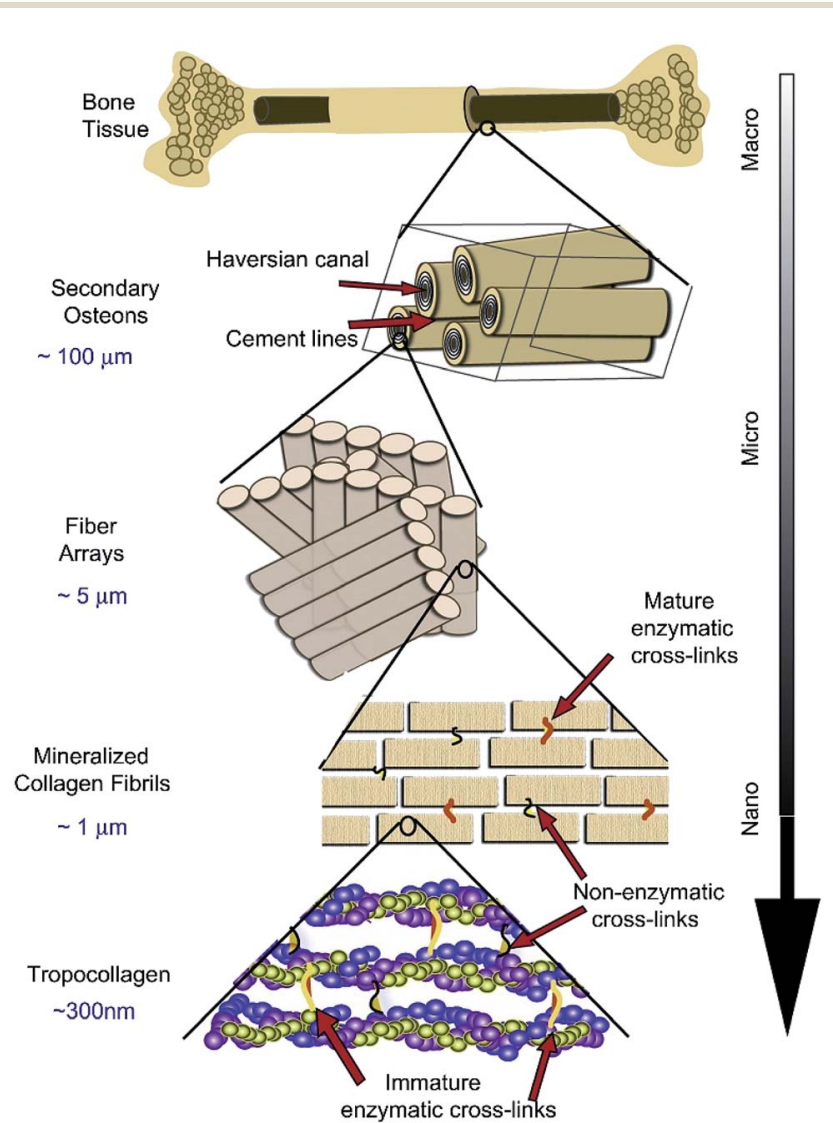

Fig. 1 Hierarchical structure of natural bone. Reproduced from ref. 11 with permission from Elsevier, copyright 2011. 
Table 1 Mechanical properties of natural bone

\begin{tabular}{|c|c|c|c|c|c|}
\hline & Modulus (GPa) & & Strength $(\mathrm{MPa})$ & & Poisson's ration \\
\hline \multirow[t]{4}{*}{ Compact bone } & Longitudinal & $17.9 \pm 3.9$ & Tension & $135 \pm 15.6$ & $0.4 \pm 0.16$ \\
\hline & & & Compression & $205 \pm 17.3$ & \\
\hline & & & Compression & $131 \pm 20.7$ & \\
\hline & Shear & $3.3 \pm 0.4$ & Shear & $65 \pm 4.0$ & \\
\hline Trabecular bone & Vertebra & $0.067 \pm 0.045$ & & $2.4 \pm 1.6$ & \\
\hline
\end{tabular}

Table 2 Chemical composition of bone (wt\%)

\begin{tabular}{ll}
\hline Inorganic Phase & Organic Phase \\
\hline $\mathrm{HA} \approx 60$ & Collagen $\approx 20$ \\
$\mathrm{H} 2 \mathrm{O} \approx 9$ & Noncollagenous proteins $\approx 3$ \\
Carbonate $\approx 4$ & Traces: polysaccharides, lipids, and cytokines \\
$\mathrm{Citrate} \approx 0.9$ & Primary bone cell: osteoblasts, osteocytes, and osteoclasts \\
$\mathrm{Na}^{+} \approx 0.7$ & \\
$\mathrm{Mg}^{2+} \approx 0.5$ & \\
$\mathrm{Cl}^{-}$ & \\
$\mathrm{Others}^{+} \mathrm{K}^{+}, \mathrm{F}^{-}, \mathrm{Zn}^{2+}, \mathrm{Fe}^{2+}, \mathrm{Cu}^{2+}, \mathrm{Sr}^{2+}$, and $\mathrm{Pb}^{2+}$ &
\end{tabular}

\subsection{Mechanical properties of bone}

The mechanical properties of natural bone vary greatly with respect to age and the body part. Young's modulus and yield stress of natural bone are anisotropic. A complete understanding of the mechanics of living bones remains an important scientific challenge. Table 1 shows the mechanical properties of natural bone obtained from the reported data. ${ }^{18}$ The longitudinal direction of the compact bone is robuster and stiffer than its transverse direction. The trabecular bone has a porous structure, and the porosity and arrangement of the individual trabeculae determine its mechanical properties.

\subsection{Natural composition of bone}

The understanding of the material components of natural bone plays a crucial role in the selection of scaffold materials. Natural bone consists of cells, ECM assembled from collagen fibrils and

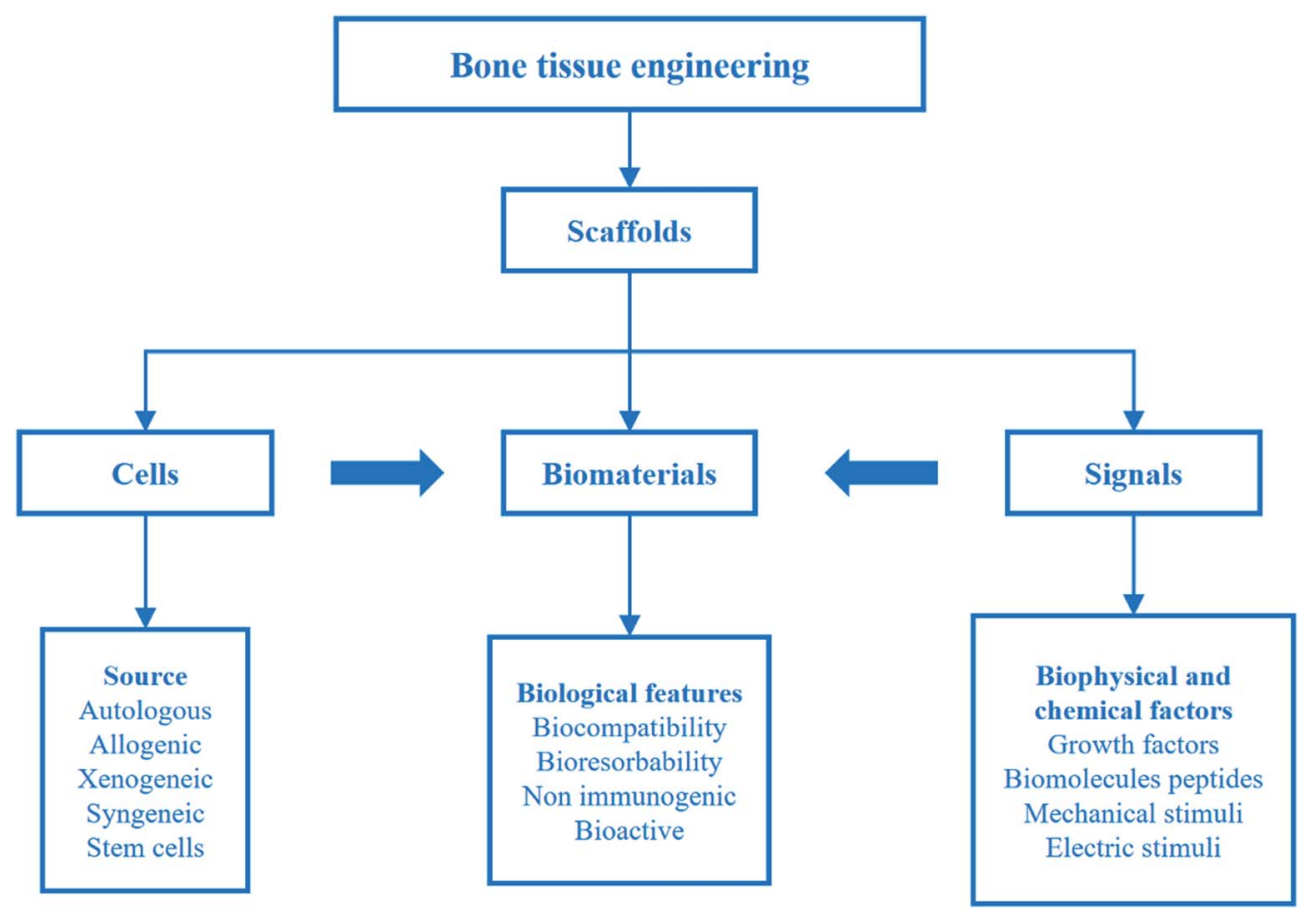

Fig. 2 Strategies for bone tissue engineering. Reproduced from ref. 22 with permission from Springer, copyright 2018. 
a

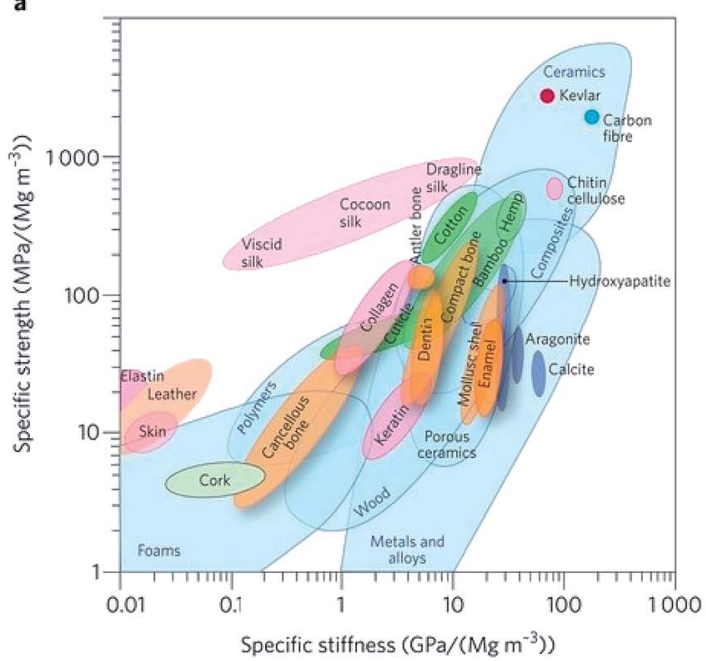

b

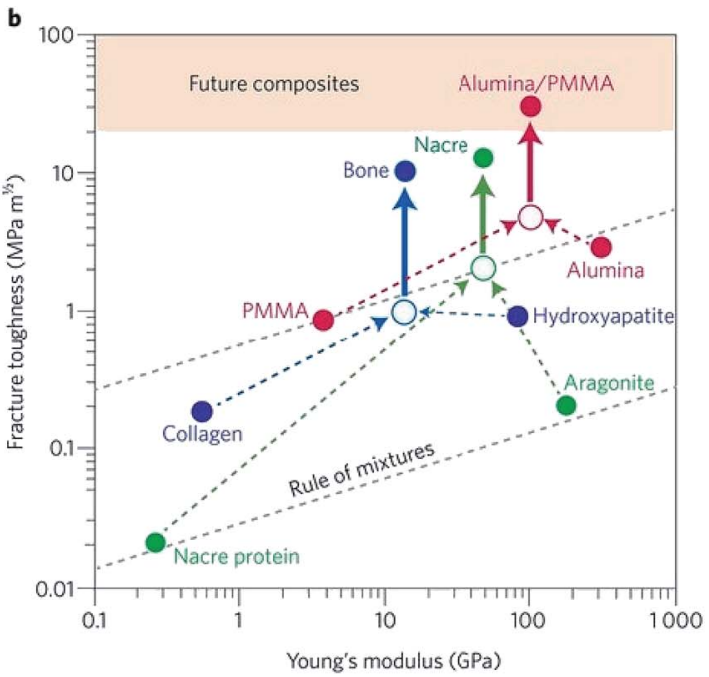

Fig. 3 Performance of natural and synthetic materials. (a) Ashby chart of strength and stiffness for natural and synthetic materials. (b) Calculation for natural and synthetic materials. Reproduced from ref. 17 with permission from Nature Publishing Group, copyright 2014

hydroxyapatite (HA), and bound minerals. Collagen and HA together account for $\sim 95 \%$ of natural bone under dry conditions. ${ }^{21}$ The composition of natural bone is presented in Table $2 .{ }^{19}$ Biological apatites deviate from the stoichiometric composition of HA and contain certain amounts of ion substitution impurities such as $\mathrm{Na}^{+}, \mathrm{Mg}^{2+}, \mathrm{Cl}^{-}, \mathrm{K}^{+}, \mathrm{F}^{-}$, and $\mathrm{Zn}^{2+}$. HA is the major inorganic component of human skeleton.

\section{Bone tissue engineering}

Although human bones have a certain self-healing ability, they are powerless for large bone defects. To overcome the problems, bone tissue engineering is proposed on the basis of tissue engineering. Bone tissue engineering aims to induce new tissue repairing and regeneration by the synergy of cells, signals and scaffolds. ${ }^{8}$ A scaffold composed of biomaterials is a carrier of cells and signals. It plays a key role in bone tissue engineering. Strategies for bone tissue engineering are shown in Fig. $2 .^{22}$

For the large-sized tissues and origins with different shapes, it is necessary to design a temporary support to provide spaces for cell proliferation, differentiation and growth. The support is called scaffold, transplant, template or artificial ECM. As noticed before, an ideal scaffold should have biocompatibility, suitable mechanical properties, high porosity and gradient pore structure. As the new tissue grows, the implanted scaffold gradually degrades until the new tissue completely replaces it. The design and fabrication of scaffolds with customization can be obtained by computer-aided design and computer-aided manufacturing (CAD/CAM) technology. Biomaterials are an important part of the scaffolds, and an ideal biomaterial should possess the following characteristics: (1) biocompatibility; (2) biodegradability; (3) easy printing and processing. During the last decades, researchers have shown increasing interest towards biomaterials for their application in bone tissue engineering scaffolds.

Generally, the obtained scaffolds should be biologically investigated. The main approaches of biological research in vitro as forecasting test before pre-clinical can be divided into two main categories: (1) in vitro culture experiments such as scaffold toxicity tests, animal or human cells (such as BMSCs, ${ }^{23}$ hMSCs, ${ }^{24}$ etc.) and (2) in vivo animal experiments (such as repairing of femur defects in rats). ${ }^{25}$ Scaffolds with non-toxic, good biocompatibility are the basis of bone repair and regeneration, in which biomaterials play an important role in the excellent performance of the scaffolds.

\section{Various biomaterials for bone tissue engineering scaffolds}

\subsection{History of biomaterials}

In the long history of human development, tissues and organs have evolved with respect to function after millions of years, but humans have been using artificial substitutes to repair damaged tissues only for decades. In the year $659 \mathrm{AD}$, the Chinese first used dental amalgam to repair defects in teeth. ${ }^{26}$ The limitations of bone replacement materials have resulted in the utilization of synthetic alternative materials for bone repair, replacement and enhancement. "Biomaterials" appeared in the early 1960s. ${ }^{7}$ The history of using biomaterials for scaffolds based on three different generations is briefly introduced below. ${ }^{\mathbf{8}}$

The first generation of biomaterials appeared in the $1960 \mathrm{~s}^{27}$ It aimed to achieve the performance of the biomaterial to match the replaced tissue with the least toxic reaction to the host. They are generally bioinert, and interact minimally with the surrounding tissues. The first generation of biomaterials mainly includes: metals (such as titanium or titanium alloys), synthetic polymers (such as PMMA and PEEK) and ceramics (such as alumina and zirconia).

The most important feature of the second-generation biomaterials is their bioactive nature, and some could be biodegradable in vivo. They consist of synthetic and natural polymers (e.g. collagen), calcium phosphates, calcium carbonate, calcium sulfates, and bioactive glasses. 
Table 3 Outlined characteristics of various biomaterials used to fabricate bone tissue engineering scaffolds

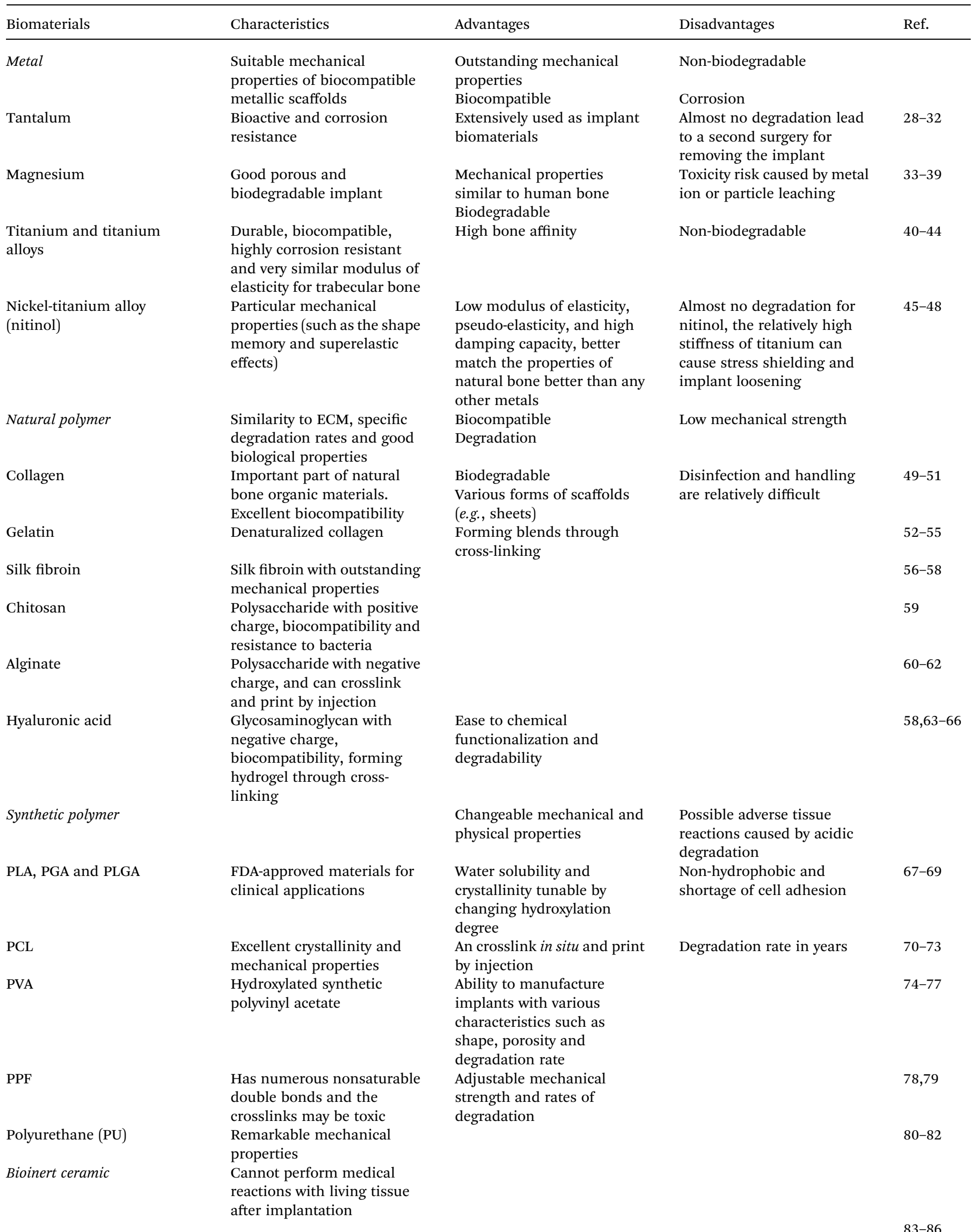


Table 3 (Contd.)

\begin{tabular}{|c|c|c|c|c|}
\hline Biomaterials & Characteristics & Advantages & Disadvantages & Ref. \\
\hline $\begin{array}{l}\text { Aluminum, e.g., } \alpha- \\
\text { aluminum oxide }\left(\mathrm{Al}_{2} \mathrm{O}_{3}\right)\end{array}$ & $\begin{array}{l}\text { Improve mechanical } \\
\text { properties; lack of biological } \\
\text { activity }\end{array}$ & & & \\
\hline Zirconia & $\begin{array}{l}\text { Interconnected structures; } \\
\text { lack of chemical bonds and } \\
\text { biological reactions between } \\
\text { living tissues }\end{array}$ & & & $87-89$ \\
\hline HA & $\begin{array}{l}\text { The main inorganic } \\
\text { component of natural bone }\end{array}$ & $\begin{array}{l}\text { Highly biocompatible, non- } \\
\text { toxic and osteoconductive }\end{array}$ & & $6,85,90,91$ \\
\hline $\begin{array}{l}\text { Tricalcium phosphate (TCP), } \\
\text { e.g., beta-tricalcium } \\
\text { phosphate }(\beta-\mathrm{TCP})\end{array}$ & $\begin{array}{l}\text { The ratio of calcium to } \\
\text { phosphorus is close to } \\
\text { natural bone tissue }\end{array}$ & $\begin{array}{l}\text { Biocompatibility, no } \\
\text { rejection and can provide } \\
\text { calcium and phosphorus for } \\
\text { new tissue }\end{array}$ & $\begin{array}{l}\alpha \text {-TCP has excessive } \\
\text { dissolution and rapid } \\
\text { degradation } \\
\text { Degradation rate and } \\
\text { osteogenic speed are } \\
\text { inconsistent }\end{array}$ & $56,92-95$ \\
\hline Calcium sulfate $\left(\mathrm{CaSO}_{4}\right)$ & $\begin{array}{l}\mathrm{CaSO}_{4} \text { is a good material to } \\
\text { choose after tumor resection }\end{array}$ & & & $96-99$ \\
\hline Akermanite (ca, Si, Mg) & $\begin{array}{l}\text { Excellent mechanical } \\
\text { properties and controllable } \\
\text { degradation rate } \\
\text { Better osteogenic } \\
\text { differentiation and } \\
\text { increased gene expression } \\
\text { compared to } \beta \text {-TCP }\end{array}$ & & & $100-102$ \\
\hline Diopside $\left(\mathrm{MgCaSi}_{2} \mathrm{O}_{6}\right)$ & $\begin{array}{l}\text { Low temperature and fast } \\
\text { firing and good thermal } \\
\text { expansion properties }\end{array}$ & & & 103-106 \\
\hline
\end{tabular}

The third generation of biomaterials are designed to induce specific beneficial biological responses by the addition of instructive substances based on the second-generation biomaterials with excellent properties and/or new biomaterials with outstanding performance. Some of the instructive substances include, but are not limited to, biological factors or external stimuli.

\subsection{Simple biomaterial scaffolds}

Biomaterials such as metals, natural polymers, synthetic polymers, ceramics, and their composites have been widely used in biomedical fields for decades. Fig. 3a indicates the values (normalized by density) of stiffness and the strength of various materials by an Ashby plot. ${ }^{17}$ Natural materials, except silk that exhibits excellent toughness, have much lower values of strength and toughness than engineering materials. However, many natural materials have a toughness value that far exceeds their composition and their homogeneous mixture (as shown by the dashed line in Fig. 3b). ${ }^{17}$ Selection of matrix material plays a crucial role in the properties of bone scaffolds. Various polymers have been developed to fabricate bone tissue engineering scaffolds. An overview of different biomaterials including their characteristics, advantages, and disadvantages is given in Table 3.

\subsection{Composite biomaterial scaffolds}

Composite biomaterials are designed to combine two or more materials. The purpose of using composite materials is mainly to improve the processability, printing performance, mechanical properties and bioactivity of the scaffolds. Ti6Al4V, HA, $\beta$ TCP and BG are widely used as bioactive biomaterials due to specific biological reactions between scaffolds and living tissues. Bioresorbable biomaterials applied in bone tissue engineering are generally natural polymers (such as collagen, gelatin, silk fibroin, and chitosan), synthetic polymers (such as PLA, PGA, and PCL) and ceramic (such as HA, $\beta$-TCP, and BGs). Scaffolds containing additives (such as GFs) have been used in clinical applications because of their excellent bone regeneration capabilities. The general composite biomaterial scaffolds with additives (signaling molecules, stem cells, functional materials, and so on) for bone tissue engineering are summarized in Table 4, which include metal matrix composites, polymer matrix composites, ceramic matrix composites, and functional composites.

Bioactive metal matrix composites are widely used in clinical medical settings because of their outstanding mechanical properties, excellent biocompatibility, thermal stability, and corrosion resistance. Titanium, tantalum and their respective 
Table 4 Summary of composites materials used to manufacture scaffolds for bone tissue engineering

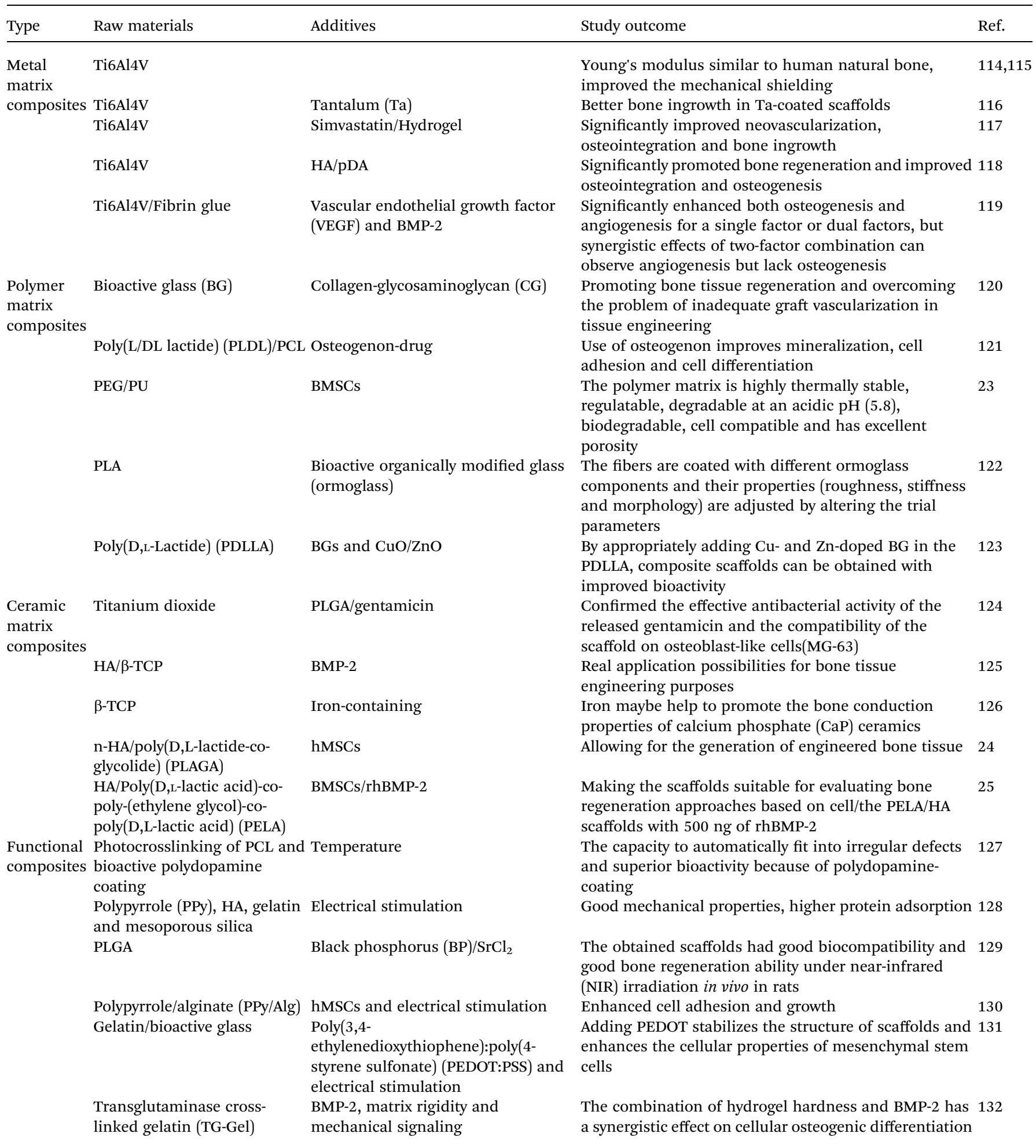

alloys are considered to be the preferred biomaterials for scaffolds. However, the high costs of manufacturing scaffolds limit their widespread development. Ti6Al4V is an outstanding representative of metal matrix composites. Young's modulus of the suitable porous Ti6Al4V scaffolds can be similar to natural bone and improve the mechanical shielding to the living tissue. ${ }^{144,115}$ The Ti6Al4V scaffolds can significantly increase bone ingrowth, osteointegration, and osteogenesis by covering the tantalum coating, ${ }^{116}$ adding simvastatin/hydrogel, ${ }^{117}$ or polydopamine-assisted hydroxyapatite coating (HA/pDA), ${ }^{118}$ as summarized in Table 4. Although metal matrix composites, such as Ti6Al4V, have many outstanding advantages; the nonbiodegradable properties of metal matrix composites fundamentally limit their potential to become ideal materials. 


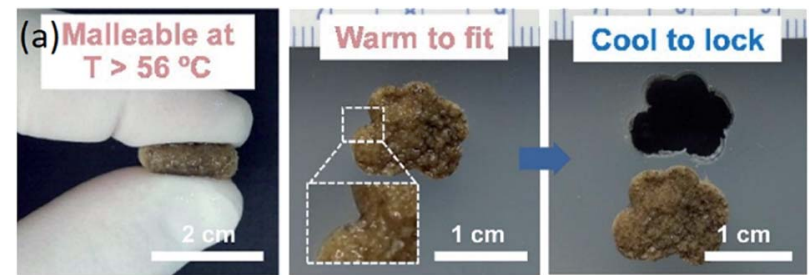

(b)
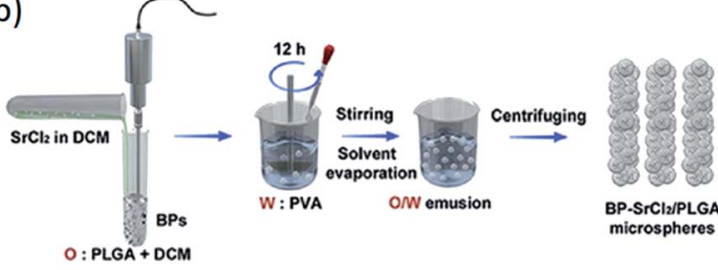

Pr.SrCl/PLGA

$D: P L G A+D C M$

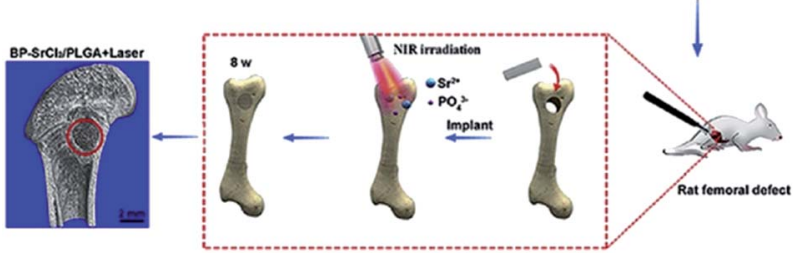

Fig. 4 Functional composite bone tissue engineering scaffolds. (a) Effect of temperature on the scaffolds. Reproduced from ref. 127 with permission from Elsevier, copyright 2014. (b) Effect of near-infrared light on the scaffolds. Reproduced from ref. 129 with permission from Elsevier, copyright 2018

In recent years, the application of polymer matrix composites and ceramic matrix composites has made great progress in bone tissue engineering scaffolds. Polymer composites have various excellent properties, such as biodegradability and mechanical properties. ${ }^{122-131}$ Ceramic materials, especially HA, are the main inorganic constituents of natural bone. ${ }^{19}$ Composite materials composed of ceramic materials and polymer materials have desirable properties for the manufacturing of scaffolds for bone tissue engineering. ${ }^{125,126,130,131}$ The composite scaffolds with additives (signaling molecules, stem cells and functional materials) have superior performance compared to just composite scaffolds (Table 4). The composite scaffolds with additives could further enhance the performance of the scaffolds. As shown in Fig. 4a, scaffolds with bioactive polydopamine coating have the capacity to automatically fit into irregular defects at higher temperatures. Wang et al. fabricated BP-SrCl $/$ /PLGA scaffolds for rat femoral defects, and the nearinfrared light-triggered platform significantly enhanced bone regeneration, as seen in Fig. 4b. ${ }^{129}$

\section{Conclusion}

In this paper, the summarized literature, which involves biomaterials for bone tissue engineering scaffolds, has been reviewed. The application and properties of various biomaterials used to fabricate scaffolds have also been elaborated. In particular, composite materials such as metal matrix composites, polymer matrix composites, ceramic matrix composites, and functional composites have been discussed. It was found that additives such as signaling molecules, stem cells, and functional materials can enhance the performance of the scaffolds. Although it was impossible forty years ago to find a material that is not repelled by living tissue, nowadays biomaterials have been used for bone repair. Improved performance of ideal biomaterials is required for their positive interactions with host tissues. The approaches for bone regeneration will make giant steps with the exploitation of novel biomaterials and new strategies, particularly the deep integration of nanotechnology, stem cell science and other fields.

\section{Abbreviations}

\begin{tabular}{|c|c|}
\hline $3 \mathrm{D}$ & Three-dimensional \\
\hline ECM & Bone extracellular matrix \\
\hline GFs & Growth factors \\
\hline CPs & Conducting polymers \\
\hline $\mathrm{MeSH}$ & Medical subject heading \\
\hline $\mathrm{BS} / \mathrm{BV}$ & Bone surface to bone volume \\
\hline HA & Hydroxyapatite \\
\hline n-HA & Nano-hydroxyapatite \\
\hline CAD & Computer-aided design \\
\hline CAM & Computer-aided manufacturing \\
\hline PMMA & Poly(methyl methacrylate) \\
\hline PEEK & Polyether ether ketone \\
\hline PLA & Poly(lactic acid) \\
\hline PGA & Poly(glycolic acid) \\
\hline PLGA & Poly(lactic-co-glycolic acid) \\
\hline PVA & Poly(vinyl alcohol) \\
\hline PPF & Poly(propylene fumarate) \\
\hline PU & Polyurethane \\
\hline $\mathrm{Al}_{2} \mathrm{O}_{3}$ & $\alpha$-Aluminum oxide \\
\hline TCP & Tricalcium phosphate \\
\hline$\beta$-ТCP & beta-tricalcium phosphate \\
\hline $\mathrm{CaP}$ & Calcium phosphate \\
\hline $\mathrm{CaSO}_{4}$ & Calcium sulphate \\
\hline $\begin{array}{l}\mathrm{HA} / \\
\mathrm{pDA}\end{array}$ & polydopamine-assisted hydroxyapatite coating \\
\hline Ta & Tantalum \\
\hline CG & Collagen-glycosaminoglycan \\
\hline PLDL & Poly(L/DL lactide) \\
\hline BP & Black phosphorus \\
\hline NIR & Near-infrared \\
\hline BMSCs & Bone marrow stromal cells \\
\hline PEG & Poly-(ethylene glycol) \\
\hline PDLLA & Poly(D,L-Lactide) \\
\hline BMP-2 & Bone morphogenetic protein 2 \\
\hline VEGF & Vascular endothelial growth factor \\
\hline PELA & $\begin{array}{l}\text { Poly(D,L-lactic acid)-co-poly-(ethylene glycol)-co- } \\
\text { poly(D,L-lactic acid) }\end{array}$ \\
\hline PLAGA & Poly(D,L-lactide-co-glycolide) \\
\hline $\begin{array}{l}\text { rhBMP- } \\
2\end{array}$ & Recombinant human bone morphogenetic protein- 2 \\
\hline PPy/Alg & Polypyrrole/alginate \\
\hline hMSCs & Human mesenchymal stem cells \\
\hline PEDOT & $\begin{array}{l}\text { PSS poly(3,4-ethylenedioxythiophene): poly(4-styrene } \\
\text { sulfonate) }\end{array}$ \\
\hline TG-Gel & Transglutaminase cross-linked gelatin \\
\hline
\end{tabular}




\section{Conflicts of interest}

There are no conflicts to declare.

\section{Acknowledgements}

This research was supported by National Natural Science Foundation of China (81704054).

\section{References}

1 M. R. Brinker and D. P. O'Connor, J. Bone Jt. Surg., 2004, 86A, 290-297.

2 B. Baroli, J. Pharm. Sci., 2009, 98, 1317-1375.

3 C. Laurencin, Y. Khan and S. F. El-Amin, Expert Rev. Med. Devices, 2006, 3, 49-57.

4 X. H. Wang, Q. Ao, X. H. Tian, J. Fan, Y. J. Wei, W. J. Hou, H. Tong and S. L. Bai, Materials, 2016, 9, 23.

5 R. Langer and J. P. Vacanti, Science, 1993, 260, 920-926.

6 S. V. Dorozhkin, Biomaterials, 2010, 31, 1465-1485.

7 F. Burny, M. Donkerwolcke and D. Muster, Materials Science and Engineering: A, 1995, 199, 53-59.

8 X. H. Yu, X. Y. Tang, S. V. Gohil and C. T. Laurencin, $A d v$. Healthc. Mater., 2015, 4, 1268-1285.

9 G. Brunello, S. Sivolella, R. Meneghello, L. Ferroni, C. Gardin, A. Piattelli, B. Zavan and E. Bressan, Biotechnol. Adv., 2016, 34, 740-753.

10 W. Yu, X. Sun, H. Y. Meng, B. C. Sun, P. Chen, X. J. Liu, K. H. Zhang, X. Yang, J. Peng and S. B. Lu, Biomater. Sci., 2017, 5, 1690-1698.

11 H. D. Barth, E. A. Zimmermann, E. Schaible, S. Y. Tang, T. Alliston and R. O. Ritchie, Biomaterials, 2011, 32, 88928904.

12 J. Y. Rho, L. Kuhn-Spearing and P. Zioupos, Med. Eng. Phys., 1998, 20, 92-102.

13 S. Weiner and H. D. Wagner, Annu. Rev. Mater. Res., 1998, 28, 271-298.

14 P. Fratzl, H. S. Gupta, E. P. Paschalis and P. Roschger, J. Mater. Chem., 2004, 14, 2115-2123.

15 P. Fratzl and R. Weinkamer, Prog. Mater. Sci., 2007, 52, 1263-1334.

16 M. J. Olszta, X. G. Cheng, S. S. Jee, R. Kumar, Y. Y. Kim, M. J. Kaufman, E. P. Douglas and L. B. Gower, Mater. Sci. Eng. R Rep., 2007, 58, 77-116.

17 U. G. K. Wegst, H. Bai, E. Saiz, A. P. Tomsia and R. O. Ritchie, Nat. Mater., 2015, 14, 23-36.

18 X. J. Wang, S. Q. Xu, S. W. Zhou, W. Xu, M. Leary, P. Choong, M. Qian, M. Brandt and Y. M. Xie, Biomaterials, 2016, 83, 127-141.

19 N. Eliaz and N. Metoki, Materials, 2017, 10, 104.

20 S. Elsharkawy and A. Mata, Adv. Healthc. Mater., 2018, 7, 19.

21 H. S. Ma, C. Feng, J. Chang and C. T. Wu, Acta Biomater., 2018, 79, 37-59.

22 Pearlin, S. Nayak, G. Manivasagam and D. Sen, Curr. Osteoporos. Rep., 2018, 16, 169-181.

23 R. Geesala, N. Bar, N. R. Dhoke, P. Basak and A. Das, Biomaterials, 2016, 77, 1-13.
24 Q. Lv, M. Deng, B. D. Ulery, L. S. Nair and C. T. Laurencin, Clin. Orthop. Relat. Res., 2013, 471, 2422-2433.

25 A. B. Kutikov, J. D. Skelly, D. C. Ayers and J. Song, ACS Appl. Mater. Interfaces, 2015, 7, 4890-4901.

26 M. E. Ring, Dentistry: An Illustrated History, Abrams, Inc., New York, 1985.

27 B. D. Ratner, A. S. Hoffman, F. J. Schoen and J. E. Lemons, Biomaterials Science: An Introduction to Materials in Medicine, Elsevier, San Diego, 2004.

28 K. Alvarez and H. Nakajima, Materials, 2009, 2, 790-832.

29 S. Bose, M. Roy and A. Bandyopadhyay, Trends Biotechnol., 2012, 30, 546-554.

30 K. Jamil, K. H. Chua, S. Joudi, S. L. Ng and N. H. Yahaya, J. Orthop. Surg. Res., 2015, $10,27$.

31 A. Jonitz, K. Lochner, T. Lindner, D. Hansmann, A. Marrot and R. Bader, J. Mater. Sci.: Mater. Med., 2011, 22, 20892095.

32 D. A. Shimko, V. F. Shimko, E. A. Sander, K. F. Dickson and E. A. Nauman, J. Biomed. Mater. Res., Part B, 2005, 73, 315324.

33 K. F. Farraro, K. E. Kim, S. L. Woo, J. R. Flowers and M. B. McCullough, J. Biomech., 2014, 47, 1979-1986.

34 K. J. Kim, S. Choi, Y. Sang Cho, S. J. Yang, Y. S. Cho and K. K. Kim, J. Mater. Sci.: Mater. Med., 2017, 28, 96.

35 Y. Li, J. Zhou, P. Pavanram, M. A. Leeflang, L. I. Fockaert, B. Pouran, N. Tumer, K. U. Schroder, J. M. C. Mol, H. Weinans, H. Jahr and A. A. Zadpoor, Acta Biomater., 2018, 67, 378-392.

36 Y. J. Liu, Z. Y. Yang, L. L. Tan, H. Li and Y. Z. Zhang, Braz. J. Med. Biol. Res., 2014, 47, 715-720.

37 M. Nabiyouni, T. Bruckner, H. Zhou, U. Gbureck and S. B. Bhaduri, Acta Biomater., 2018, 66, 23-43.

38 M. Yazdimamaghani, M. Razavi, D. Vashaee, K. Moharamzadeh, A. R. Boccaccini and L. Tayebi, Mater. Sci. Eng., C, 2017, 71, 1253-1266.

39 M. Yazdimamaghani, M. Razavi, D. Vashaee and L. Tayebi, Mater. Sci. Eng., C, 2015, 49, 436-444.

40 Y. Chen, J. E. Frith, A. Dehghan-Manshadi, H. Attar, D. Kent, N. D. M. Soro, M. J. Bermingham and M. S. Dargusch, J. Mech. Behav. Biomed. Mater., 2017, 75, 169-174.

$41 \mathrm{H}$. J. Haugen, M. Monjo, M. Rubert, A. Verket, S. P. Lyngstadaas, J. E. Ellingsen, H. J. Ronold and J. C. Wohlfahrt, Acta Biomater., 2013, 9, 5390-5399.

42 J. H. Kim, D. K. Kim, O. J. Lee, H. W. Ju, J. M. Lee, B. M. Moon, H. J. Park, D. W. Kim, J. H. Lee and C. H. Park, Int. J. Biol. Macromol., 2016, 82, 160-167.

43 J. Liu, J. Ruan, L. Chang, H. Yang and W. Ruan, Mater. Sci. Eng., C, 2017, 78, 503-512.

44 T. Takizawa, N. Nakayama, H. Haniu, K. Aoki, M. Okamoto, H. Nomura, M. Tanaka, A. Sobajima, K. Yoshida, T. Kamanaka, K. Ajima, A. Oishi, C. Kuroda, H. Ishida, S. Okano, S. Kobayashi, H. Kato and N. Saito, Adv. Mater., 2018, 30, 1703608.

45 I. Gotman, D. Ben-David, R. E. Unger, T. Bose, E. Y. Gutmanas and C. J. Kirkpatrick, Acta Biomater., 2013, 9, 8440-8448. 
46 T. Habijan, C. Haberland, H. Meier, J. Frenzel, J. Wittsiepe, C. Wuwer, C. Greulich, T. A. Schildhauer and M. Koller, Mater. Sci. Eng., C, 2013, 33, 419-426.

47 W. Hoffmann, T. Bormann, A. Rossi, B. Muller, R. Schumacher, I. Martin, M. de Wild and D. Wendt, J. Tissue Eng., 2014, 5, 2041731414540674.

48 S. Strauss, A. Neumeister, S. Barcikowski, D. Kracht, J. W. Kuhbier, C. Radtke, K. Reimers and P. M. Vogt, PLoS One, 2013, 8, e53309.

49 J. Elango, J. Zhang, B. Bao, K. Palaniyandi, S. Wang, W. Wenhui and J. S. Robinson, Int. J. Biol. Macromol, 2016, 91, 51-59.

$50 \mathrm{~J}$. Lee and G. Kim, ACS Appl. Mater. Interfaces, 2018, 10, 35801-35811.

51 Y. Wang, N. Van Manh, H. Wang, X. Zhong, X. Zhang and C. Li, Int. J. Nanomed., 2016, 11, 2053-2067.

52 T. Mazaki, Y. Shiozaki, K. Yamane, A. Yoshida, M. Nakamura, Y. Yoshida, D. Zhou, T. Kitajima, M. Tanaka, Y. Ito, T. Ozaki and A. Matsukawa, Sci. Rep., 2014, 4, 4457.

53 W. Shi, M. Sun, X. Hu, B. Ren, J. Cheng, C. Li, X. Duan, X. Fu, J. Zhang, H. Chen and Y. Ao, Adv. Mater., 2017, 29, 1701089.

54 B. Wang, Y. Guo, X. Chen, C. Zeng, Q. Hu, W. Yin, W. Li, H. Xie, B. Zhang, X. Huang and F. Yu, Int. J. Nanomed., 2018, 13, 7395-7408.

55 Y. Xia, F. Mei, Y. Duan, Y. Gao, Z. Xiong, T. Zhang and H. Zhang, J. Biomed. Mater. Res. A, 2012, 100, 1044-1050.

56 D. H. Lee, N. Tripathy, J. H. Shin, J. E. Song, J. G. Cha, K. D. Min, C. H. Park and G. Khang, Int. J. Biol. Macromol., 2017, 95, 14-23.

57 J. Melke, S. Midha, S. Ghosh, K. Ito and S. Hofmann, Acta Biomater., 2016, 31, 1-16.

58 S. Gokila, T. Gomathi, K. Vijayalakshmi, F. A. Alsharani, S. Anil and P. N. Sudha, Int. J. Biol. Macromol., 2018, 120, 876-885.

59 S. Preethi Soundarya, A. Haritha Menon, S. Viji Chandran and N. Selvamurugan, Int. J. Biol. Macromol., 2018, 119, 1228-1239.

60 Y. M. Kolambkar, K. M. Dupont, J. D. Boerckel, N. Huebsch, D. J. Mooney, D. W. Hutmacher and R. E. Guldberg, Biomaterials, 2011, 32, 65-74.

61 J. Sun and H. Tan, Materials, 2013, 6, 1285-1309.

62 J. Venkatesan, I. Bhatnagar, P. Manivasagan, K. H. Kang and S. K. Kim, Int. J. Biol. Macromol., 2015, 72, 269-281.

63 N. Cui, J. Qian, T. Liu, N. Zhao and H. Wang, Carbohydr. Polym., 2015, 126, 192-198.

64 C. Manferdini, V. Guarino, N. Zini, M. G. Raucci, A. Ferrari, F. Grassi, E. Gabusi, S. Squarzoni, A. Facchini, L. Ambrosio and G. Lisignoli, Biomaterials, 2010, 31, 3986-3996.

65 J. Patterson, R. Siew, S. W. Herring, A. S. Lin, R. Guldberg and P. S. Stayton, Biomaterials, 2010, 31, 6772-6781.

66 E. D. Pre, G. Conti and A. Sbarbati, Stem Cell Rev. Rep., 2016, 12, 664-681.

67 S. H. Zaky, K. W. Lee, J. Gao, A. Jensen, K. Verdelis, Y. Wang, A. J. Almarza and C. Sfeir, Acta Biomater., 2017, 54, 95-106.
68 Y. Boukari, O. Qutachi, D. J. Scurr, A. P. Morris, S. W. Doughty and N. Billa, J. Biomater. Sci., Polym. Ed., 2017, 28, 1966-1983.

69 W. Shao, J. He, F. Sang, Q. Wang, L. Chen, S. Cui and B. Ding, Mater. Sci. Eng., C, 2016, 62, 823-834.

70 S. H. Ahn, H. J. Lee and G. H. Kim, Biomacromolecules, 2011, 12, 4256-4263.

71 S. N. Gorodzha, A. R. Muslimov, D. S. Syromotina, A. S. Timin, N. Y. Tcvetkov, K. V. Lepik, A. V. Petrova, M. A. Surmeneva, D. A. Gorin, G. B. Sukhorukov and R. A. Surmenev, Colloids Surf., B, 2017, 160, 48-59.

72 Z. Guo, J. Xu, S. Ding, H. Li, C. Zhou and L. Li, J. Biomater. Sci., Polym. Ed., 2015, 26, 989-1001.

73 F. Sharifi, S. M. Atyabi, D. Norouzian, M. Zandi, S. Irani and H. Bakhshi, Int. J. Biol. Macromol., 2018, 115, 243-248.

74 C. Gao, Q. Gao, Y. Li, M. N. Rahaman, A. Teramoto and K. Abe, J. Biomed. Mater. Res. A, 2012, 100, 1324-1334.

75 X. Li, Y. Li, Y. Zuo, D. Qu, Y. Liu, T. Chen, N. Jiang, H. Li and J. Li, J. Biomed. Mater. Res. A, 2015, 103, 3226-3236.

76 D. Qu, J. Li, Y. Li, A. Khadka, Y. Zuo, H. Wang, Y. Liu and L. Cheng, J. Biomed. Mater. Res., Part B, 2011, 96, 9-15.

77 T. Wan, G. K. Stylios, M. Giannoudi and P. V. Giannoudis, Injury, 2015, 46(suppl. 8), S39-S43.

78 D. L. Alge, J. Bennett, T. Treasure, S. Voytik-Harbin, W. S. Goebel and T. M. Chu, J. Biomed. Mater. Res. A, 2012, 100, 1792-1802.

79 R. Mishra, B. M. Roux, M. Posukonis, E. Bodamer, E. M. Brey, J. P. Fisher and D. Dean, Biomaterials, 2016, 77, 255-266.

80 M. Meskinfam, S. Bertoldi, N. Albanese, A. Cerri, M. C. Tanzi, R. Imani, N. Baheiraei, M. Farokhi and S. Fare, Mater. Sci. Eng., C, 2018, 82, 130-140.

81 W. Yang, S. K. Both, Y. Zuo, Z. T. Birgani, P. Habibovic, Y. Li, J. A. Jansen and F. Yang, J. Biomed. Mater. Res. A, 2015, 103, 2251-2259.

82 T. Yoshii, A. E. Hafeman, J. M. Esparza, A. Okawa, G. Gutierrez and S. A. Guelcher, J. Tissue Eng. Regener. Med., 2014, 8, 589-595.

83 D. Kytyr, P. Zlamal, P. Koudelka, T. Fila, N. Krcmarova, I. Kumpova, D. Vavrik, A. Gantar and S. Novak, Mater. Des., 2017, 134, 400-417.

84 M. L. Lastra, M. S. Molinuevo, I. Blaszczyk-Lezak, C. Mijangos and M. S. Cortizo, J. Biomed. Mater. Res. A, 2018, 106, 570-579.

85 S. Mondal, G. Hoang, P. Manivasagan, M. S. Moorthy, T. P. Nguyen, T. T. V. Phan, H. H. Kim, M. H. Kim, S. Y. Nam and J. Oh, Ceram. Int., 2018, 44, 15735-15746.

86 A. Pietraszek, A. Karewicz, M. Widnic, D. Lachowicz, M. Gajewska, A. Bernasik and M. Nowakowska, Colloids Surf., B, 2019, 173, 1-8.

87 A. Afzal, Mater. Express, 2014, 4, 1-12.

88 X. Q. Huang, H. Y. Yang, T. Luo, C. Huang, F. R. Tay and L. N. Niu, Acta Biomater., 2018, 67, 366-377.

89 M. Latifi, T. Talaei-Khozani, H. Mehraban-Jahromi, M. Sani, M. Sadeghi-Atabadi, A. Fazel-Anvari and M. Kabir-Salmani, Bioinspired, Biomimetic Nanobiomater., 2018, 7, 122-130. 
90 C. Yang, Z. G. Huan, X. Y. Wang, C. T. Wu and J. Chang, ACS Biomater. Sci. Eng., 2018, 4, 608-616.

91 Y. Lei, Z. L. Xu, Q. F. Ke, W. J. Yin, Y. X. Chen, C. Q. Zhang and Y. P. Guo, Mater. Sci. Eng., C, 2017, 72, 134-142.

92 G. Fielding and S. Bose, Acta Biomater., 2013, 9, 9137-9148. 93 D. Ke and S. Bose, Mater. Sci. Eng., C, 2017, 78, 398-404.

94 R. Taktak, A. Elghazel, J. Bouaziz, S. Charfi and H. Keskes, Mater. Sci. Eng., C, 2018, 86, 121-128.

95 K. Yang, J. Zhang, X. Ma, Y. Ma, C. Kan, H. Ma, Y. Li, Y. Yuan and C. Liu, Mater. Sci. Eng., C, 2015, 56, 37-47.

96 X. Qi, P. Pei, M. Zhu, X. Du, C. Xin, S. Zhao, X. Li and Y. Zhu, Sci. Rep., 2017, 7, 42556.

97 Y. Shen, S. Yang, J. Liu, H. Xu, Z. Shi, Z. Lin, X. Ying, P. Guo, T. Lin, S. Yan, Q. Huang and L. Peng, ACS Appl. Mater. Interfaces, 2014, 6, 12177-12188.

98 C. Shuai, J. Zhou, D. Gao, C. Gao, P. Feng and S. Peng, Molecules, 2016, 21, 378.

99 Z. Zhou, F. Buchanan, C. Mitchell and N. Dunne, Mater. Sci. Eng., C, 2014, 38, 1-10.

100 A. Liu, M. Sun, X. Yang, C. Ma, Y. Liu, X. Yang, S. Yan and Z. Gou, J. Biomater. Appl., 2016, 31, 650-660.

101 H. Shokrollahi, F. Salimi and A. Doostmohammadi, J. Mech. Behav. Biomed. Mater., 2017, 74, 365-370.

102 C. Shuai, Z. Han, P. Feng, C. Gao, T. Xiao and S. Peng, J. Mater. Sci.: Mater. Med., 2015, 26, 188.

103 Z. Ba, Z. Chen, Y. Huang, D. Feng, Q. Zhao, J. Zhu and D. Wu, Int. J. Nanomed., 2018, 13, 3883-3896.

104 J. P. Kumar, L. Lakshmi, V. Jyothsna, D. R. Balaji, S. Saravanan, A. Moorthi and N. Selvamurugan, J. Biomed. Nanotechnol., 2014, 10, 970-981.

105 T. Liu, P. Wu, C. Gao, P. Feng, T. Xiao, Y. Deng, C. Shuai and S. Peng, BioMed Res. Int., 2016, 2016, 7090635.

106 C. Wu, Y. Ramaswamy and H. Zreiqat, Acta Biomater., 2010, 6, 2237-2245.

107 D. Bellucci, A. Sola, R. Salvatori, A. Anesi, L. Chiarini and V. Cannillo, Mater. Sci. Eng., C, 2014, 43, 573-586.

108 C. Bian, H. Lin, F. Zhang, J. Ma, F. Li, X. Wu and F. Qu, IET Nanobiotechnol., 2014, 8, 275-281.

109 A. Goel, S. Kapoor, R. R. Rajagopal, M. J. Pascual, H. W. Kim and J. M. Ferreira, Acta Biomater., 2012, 8, 361-372.

110 Y. Gu, W. Huang, M. N. Rahaman and D. E. Day, Acta Biomater., 2013, 9, 9126-9136.

111 A. Hoppe, N. S. Guldal and A. R. Boccaccini, Biomaterials, 2011, 32, 2757-2774.

112 B. Sarker, J. Hum, S. N. Nazhat and A. R. Boccaccini, Adv. Healthc. Mater., 2015, 4, 176-194.

113 D. Sriranganathan, N. Kanwal, K. A. Hing and R. G. Hill, J. Mater. Sci.: Mater. Med., 2016, 27, 39.

114 F. Yang, C. Chen, Q. Zhou, Y. Gong, R. Li, C. Li, F. Klampfl, S. Freund, X. Wu, Y. Sun, X. Li, M. Schmidt, D. Ma and Y. Yu, Sci. Rep., 2017, 7, 45360.
115 L. Y. Zhu, L. Li, J. P. Shi, Z. A. Li and J. Q. Yang, Am. J. Transl. Res., 2018, 10, 3443-3454.

116 X. Li, L. Wang, X. Yu, Y. Feng, C. Wang, K. Yang and D. Su, Mater. Sci. Eng., C, 2013, 33, 2987-2994.

117 H. Liu, W. Li, C. Liu, J. Tan, H. Wang, B. Hai, H. Cai, H. J. Leng, Z. J. Liu and C. L. Song, Biofabrication, 2016, 8, 045012.

118 Y. Li, W. Yang, X. Li, X. Zhang, C. Wang, X. Meng, Y. Pei, X. Fan, P. Lan, C. Wang, X. Li and Z. Guo, ACS Appl. Mater. Interfaces, 2015, 7, 5715-5724.

119 J. Lv, P. Xiu, J. Tan, Z. Jia, H. Cai and Z. Liu, Biomed. Mater., 2015, 10, 035013.

120 E. Quinlan, S. Partap, M. M. Azevedo, G. Jell, M. M. Stevens and F. J. O'Brien, Biomaterials, 2015, 52, 358-366.

121 I. Rajzer, E. Menaszek and O. Castano, Mater. Sci. Eng., C, 2017, 77, 493-499.

122 N. Sachot, M. A. Mateos-Timoneda, J. A. Planell, A. H. Velders, M. Lewandowska, E. Engel and O. Castano, Nanoscale, 2015, 7, 15349-15361.

123 J. Bejarano, R. Detsch, A. R. Boccaccini and H. Palza, J. Biomed. Mater. Res. A, 2017, 105, 746-756.

124 L. Rumian, H. Tiainen, U. Cibor, M. Krok-Borkowicz, M. Brzychczy-Wloch, H. J. Haugen and E. Pamula, Mater. Sci. Eng., C, 2016, 69, 856-864.

125 A. Abarrategi, C. Moreno-Vicente, F. J. Martinez-Vazquez, A. Civantos, V. Ramos, J. V. Sanz-Casado, R. MartinezCorria, F. H. Perera, F. Mulero, P. Miranda and J. L. Lopez-Lacomba, PLoS One, 2012, 7, e34117.

126 A. Manchon, M. Hamdan Alkhraisat, C. Rueda-Rodriguez, J. C. Prados-Frutos, J. Torres, J. Lucas-Aparicio, A. Ewald, U. Gbureck and E. Lopez-Cabarcos, Biomedical materials, Bristol, England, 2015, 10, p. 055012.

127 D. Zhang, O. J. George, K. M. Petersen, A. C. JimenezVergara, M. S. Hahn and M. A. Grunlan, Acta Biomater., 2014, 10, 4597-4605.

128 N. Zanjanizadeh Ezazi, M. A. Shahbazi, Y. V. Shatalin, E. Nadal, E. Makila, J. Salonen, M. Kemell, A. Correia, J. Hirvonen and H. A. Santos, Int. J. Pharm., 2018, 536, 241-250.

129 X. Z. Wang, J. D. Shao, M. Abd El Raouf, H. H. Xie, H. Huang, H. Y. Wang, P. K. Chu, X. F. Yu, Y. Yang, A. M. AbdEl-Aal, N. H. M. Mekkawy, R. J. Miron and Y. F. Zhang, Biomaterials, 2018, 179, 164-174.

130 S. Yang, L. Jang, S. Kim, J. Yang, K. Yang, S. W. Cho and J. Y. Lee, Macromol. Biosci., 2016, 16, 1653-1661.

131 A. Shahini, M. Yazdimamaghani, K. J. Walker, M. A. Eastman, H. Hatami-Marbini, B. J. Smith, J. L. Ricci, S. V. Madihally, D. Vashaee and L. Tayebi, Int. J. Nanomed., 2014, 9, 167-181.

132 S. Tan, J. Y. Fang, Z. Yang, M. E. Nimni and B. Han, Biomaterials, 2014, 35, 5294-5306. 